\title{
O Tribunal de Segurança Nacional e a sua atuação no Brasil dos anos 1930 e 1940
}

\author{
The National Security Court and its practice in Brazil in the 1930's and the 1940's
}

Júlia Kertesz Renault Pinto*

\begin{abstract}
REFERÊNCIA
PINTO, Júlia Kertesz Renault. O Tribunal de Segurança Nacional e a sua atuação no Brasil dos anos 1930 e 1940. Revista da Faculdade de Direito da UFRGS, Porto Alegre, n. 41, p. 120-144, dez. 2019. DOI: <https://doi.org/10.22456/0104-6594.83753>.

\section{RESUMO}

O presente artigo trata da atuação do Tribunal de Segurança Nacional, como Corte de exceção, entre os anos de 1936 e 1945. Estritamente vinculado à política militar anticomunista do Estado Novo (1937-1945), o TSN foi criado e elaborado a partir de leis de segurança nacional, que viriam a ser, durante a Ditadura Militar, uma das principais armas da repressão.
\end{abstract}

\section{PALAVRAS-CHAVE}

História do Direito. Tribunal de Segurança Nacional. Getúlio Vargas. Estado Novo.

\begin{abstract}
The present paper analyses the role of the Court of National Security, as a Court of exception, between the years of 1936 and 1945. Strictly connected to the military anti-communist policy of the Estado Novo (19371945), the Court of National Security was created and elaborated through the Laws of National Security, which would become, during the Military Dictatorship, one of the main weapons of the repression.
\end{abstract}

\section{KEYWORDS}

Legal history. Court of National Security. Getúlio Vargas. Estado Novo.

\section{SUMÁRIO}

1. Introdução. 2. Das previsões constitucionais sobre segurança - uma retrospectiva brasileira. 2.1 Do período imperial. 2.2 Do período da Primeira República. 2.3 Da Segunda República: a Revolução de 1930 e a Constituição de 1934. 3. O contexto da criação do Tribunal de Segurança Nacional. 3.1 Da promulgação da Lei de Segurança Nacional de 1935. 3.2 Da Intentona Comunista. 4. O Tribunal de Segurança Nacional. 4.1 Da lei do Tribunal de Segurança Nacional. 4.1.1 Da lei relativa à criação do Tribunal de Segurança Nacional. 4.2 A primeira fase: julgando os revoltosos da Intentona Comunista. 4.3 A segunda fase: o Tribunal de Segurança Nacional durante o Estado Novo. 4.3.1 Do Decreto-Lei no 88, de 20 de dezembro de 1937. 4.3.2 Da "Fase Verde": julgando os integralistas. 4.3.3 A atuação do Tribunal de Segurança Nacional após o putsch integralista. 4.3.4 TSN e os crimes contra a economia. 5 Conclusão. Referências. Dados da publicação.

\footnotetext{
* Advogada, com graduação pela PUC-Rio, pós-graduação lato sensu em Direitos Humanos, mestrado em Direito Constitucional pela Faculdade de Direito da Universidade de Coimbra e doutorado pela Faculdade de Direito da Universidade de Viena.
} 


\section{INTRODUÇÃO}

O objetivo do presente trabalho consiste em analisar o papel atribuído ao Tribunal de Segurança Nacional (TSN), como corte de exceção, entre o período de 1936 a 1945.

Primeiramente, criado com o objetivo de punir os responsáveis pela Intentona Comunista de 1935, o Tribunal do Estado Novo, a partir de 1937, passou a julgar suspeitos de discordar do regime vigente.

Trata-se, portanto, de evidenciar como e porque o TSN foi criado, os fatos e as situações que possibilitaram a sua criação e as transformações pelas quais passou, desde a sua criação, em 1936, até a sua extinção, em 1945.

Evidentemente que tratar do TSN implica, necessariamente, revelar a extrema importância do papel dos militares, sua influência para a construção de tão estranha e severa Corte que, no seu primeiro momento, funcionou como órgão da Justiça Militar.

$\mathrm{O}$ presente trabalho está dividido em três partes. $\mathrm{Na}$ primeira, para fins de enquadramento teórico, analisaremos a relação entre os militares e a segurança no Brasil. Como veremos, os militares são estritamente ligados às ideias de segurança e ordem. Essa vinculação, em que a segurança acaba por ser o objetivo da própria organização militar, demonstra a influência e a conduta singular que os militares desempenharam no âmbito jurídico brasileiro.

Na segunda parte do trabalho, faremos um percurso histórico-jurídico, que nos levará à criação do TSN. O contexto, bem como as razões pelas quais o Tribunal em questão foi criado, são cruciais, para adentrarmos, propriamente, na atuação deste.

A terceira parte do trabalho será dedicada ao TSN. Serão analisados aspectos relacionados à sua atuação, assim como a algumas de suas decisões, além das leis que as embasaram. A seguir, apresentamos as conclusões.

\section{DAS PREVISÕES CONSTITUCIONAIS SOBRE SEGURANÇA - UMA RETROSPECTIVA BRASILEIRA}

A segurança nacional é, geralmente, concebida como uma doutrina, cujos contornos se formaram com o fenômeno da Guerra Fria. 
No Brasil, a segurança nacional é associada à criação da Escola Superior de Guerra, em $1949^{1}$. Esta teria desenvolvido e adaptado a concepção de segurança nacional ao contexto brasileiro, baseando-se, precipuamente, na ideia do inimigo interno. Sem excluirmos essa análise, preferimos compreender a segurança nacional como um movimento expressivo, partido, principalmente, dos militares em momentos anteriores à criação da Escola Superior de Guerra. Como veremos posteriormente, a própria criação do TSN é um exemplo disso.

Essa relação entre os militares e a segurança do País é de extrema relevância para entendermos e analisarmos os motivos pelos quais o TSN foi criado, bem como as leis que o embasaram e lhe deram suporte jurídico.

Primeiramente, faremos uma análise, a partir das Constituições brasileiras, de como a segurança foi prevista, bem como a sua inter-relação com os militares.

\subsection{Do período imperial}

A Carta outorgada em 1824 previa, no art. 102, inciso XV, que cabia ao Imperador, como chefe do Poder Executivo, "prover a tudo, que for concernente à segurança interna, $e$ externa do Estado, na forma da Constituição".

A defesa contra os inimigos internos e externos foi atribuído à Força Militar, por meio da atuação de todos os brasileiros. O art. 145 previa que: "todos os brasileiros são obrigados a pegar em armas para sustentar a independência e integridade do Império, e defendê-lo dos seus inimigos externos ou internos" ${ }^{2}$. Em relação a essa previsão, cabe uma ressalva: a instituição que, de fato, exerceu relevância, no âmbito da segurança interna do País, foi a chamada Guarda Nacional, fruto das antigas milícias locais ${ }^{3}$.

A Guarda Nacional foi criada em 1831, tendo extinto as organizações antigas, as Ordenanças e Milícias, e substituído as organizações até então recentes, as Guardas

\footnotetext{
${ }^{1}$ Sobre a Doutrina de Segurança Nacional: COMBLIN, Joseph. A Ideologia da Segurança Nacional: o Poder Militar na América Latina. 3. ed. Rio de Janeiro: Civilização Brasileira, 1980; ALVES, Maria Helena Moreira. Estado e Oposição no Brasil (1964-1984). 3. ed. Rio de Janeiro: Vozes, 1985; ARQUIDIOCESE DE SÃO PAULO. Brasil: Nunca mais, 8. ed. Rio de Janeiro: Vozes, 1985; PESSOA, Mário. O Direito da Segurança Nacional. Rio de Janeiro: Biblioteca do Exército; Revista dos Tribunais, 1971.

${ }^{2}$ Também em relação à Força Armada, o art. 147 e o art. 148 dispõem: Art. 147. A Força Militar é essencialmente obediente; jamais se poderá reunir sem que lhe seja ordenado pela Autoridade legítima. Art. 148. Ao Poder Executivo compete privativamente empregar a Força Armada de Mar e Terra como bem lhe parecer conveniente à segurança e defesa do Império.

${ }^{3}$ SODRÉ, Nelson Werneck. A História Militar do Brasil. 3. ed. Rio de Janeiro: Civilização Brasileira, 1979. p. 116-143.
} 
Municipais ${ }^{4}$. A Guarda Nacional representava o papel secundário conferido ao Exército. Este era responsável pela defesa externa do País, enquanto à Guarda Nacional foi atribuída responsabilidade pelas operações contra inimigos internos. "Assim, o Estado confiava muito mais na Guarda Nacional do que no Exército para a repressão interna" 5.

O papel secundário, atribuído às Forças Armadas, estava relacionado ao desejo de ascensão e manutenção de poderes regionais, em que pouco havia lugar para as noções de unidade nacional ${ }^{6}$. A desconfiança em relação às Forças Armadas ocorria em virtude das suspeitas de que estas não se identificavam com os interesses regionais, ao contrário da Guarda Nacional, composta por forças milicianas de cidadãos ${ }^{7}$.

O inimigo interno da época eram aqueles contrários à independência do Brasil, imagem geralmente atribuída aos portugueses ${ }^{8}$. Por isso, não é de se estranhar que aos militares fosse relegada a defesa das fronteiras, ao mesmo tempo em que às forças milicianas, compostas por civis, coubesse a defesa interna do País, o combate ao inimigo interno 9 .

A mudança no papel desempenehado pelos militares ocorreu com o advento da República, após a Guerra do Paraguai ${ }^{10}$. Há quem considere, inclusive, a implantação da República como um golpe militar, pensado por Benjamin Constant e executado por Deodoro da Fonseca ${ }^{11}$. Seria o Exército que, após a vitória da Guerra do Paraguai, "toma consciência da sua força e unidade e elege seus heróis e líderes"12. Não por acaso, o primeiro Presidente foi um Marechal do Exército, Deodoro da Fonseca.

\footnotetext{
${ }^{4}$ SODRÉ, Nelson Werneck. A História Militar do Brasil. 3. ed. Rio de Janeiro: Civilização Brasileira, 1979. p. 119.

${ }^{5}$ Ibidem, p. 127.

${ }^{6}$ COELHO, Edmundo Campos. Em Busca de Identidade: o Exército e a Política na Sociedade Brasileira. Rio de Janeiro: Forense Universitária, 1976. p. 34-38.

${ }^{7}$ A Guarda Nacional só viria a ser extinta em 12 de janeiro de 1918, passando a constituir o Exército de $2^{\mathrm{a}}$ linha.

${ }^{8}$ Ver: CERQUEIRA, Marcello. A Constituição na História: Origem e Reforma. Rio de Janeiro: Revan, 1993. p. 272.

${ }^{9}$ Ver: CARVALHO, José Murilo de. As Forças Armadas na Primeira República: o Poder Desestabilizador. In: CARVALHO, José Murilo de. Forças Armadas e Política no Brasil. Rio de Janeiro: Jorge Zahar Editor, 2005. p. 15.

${ }^{10}$ Carlos Maximiliano relata as palavras proferidas por Joaquim Nabuco: “A guerra com o Paraguay teve importância tão decisiva sobre o nosso destino nacional (...). Ella marca o apogêo do Imperio, mas também procedem della as causas principaes da decadência e da quéda da dynastia: o aspecto e o desenvolvimento do Prata com a fascinação que elle exerce, o ascendente militar (pelos nomes chamados legendários, pelas reivindicações da classe, tendo á frente os homens que se deram a conhecer ao exército e se ligaram entre si pela camaradagem da campanha); o americanismo; a própria emancipação dos escravos, que por diversos modos se prende á guerra (residencia em paizes sem escravos, de milhares de brasileiros de todas as classes; ultrages constantes ao Brasil, por causa da escravidão, por parte dos inimigos e da Aliança; inferioridade militar effectiva por esse motivo). MAXIMILIANO, Carlos. Commentarios à Constituição Brasileira. 3. ed. Porto Alegre: Livraria do Globo, 1929. p. 34-35.

${ }^{11}$ SILVA, Hélio. O Poder Militar. 2. ed. Porto Alegre: L\&PM Editores, 1985. p. 44.

12 Ibidem, p. 33.
} 
A Constituição de 1891, a primeira Constituição republicana do País, demonstra claramente as modificações no âmbito militar em relação à segurança.

\subsection{Do período da Primeira República}

Com a Constituição de 1891, as Forças Armadas tornaram-se responsáveis pela manutenção das leis no interior do País, precedente este que seria enfatizado ao longo das demais Constituições. Começava, portanto, um movimento de aumento de poder dos militares, que passariam a chamar para si o dever de resguardar a segurança, a lei e a ordem.

Paralelamente, a ideia de segurança nacional acentuava-se, ganhando novos contornos com o surgimento, no século XIX, de novos atores na sociedade brasileira. A concepção de um inimigo a ser combatido, inimigo estranho, portanto, e ameaçador de uma suposta ordem estabelecida surgia antes mesmo de a corrente comunista ingressar ideologicamente no Brasil. O trabalho industrial, a presença do imigrante e a organização sindical, que daí começava a ser montada, seriam os primeiros grandes inspiradores da doutrina brasileira de segurança nacional $^{13}$. Com o advento da República, havia ainda mais um inimigo interno, os inimigos da República.

Foi nesse contexto que o Decreto $\mathrm{n}^{\mathrm{o}} 85$ - A foi editado por Deodoro da Fonseca ${ }^{14}$. Conhecido como "decreto-rolha", por instituir censura à imprensa, previa a criação da Comissão Mista Militar de Sindicâncias e Julgamentos, cujos integrantes seriam indicados pelo Ministro da Guerra. O objetivo da Comissão, uma junta militar, consistia em julgar civis e militares que cometessem atos considerados ameaçadores à nova ordem política. A Comissão chegou a sentenciar penas de morte, mas, todas comutadas pelo governo em prisão perpétua $^{15}$.

Outro decreto a ser destacado é o Decreto no 1641, de 1907, que "trata da expulsão de estrangeiros que comprometerem a segurança nacional ou a tranquilidade pública", cujo objetivo consistia em atacar, especialmente, lideranças sindicais, fossem elas ligadas, ou não, ao anarquismo, mas que eram reconhecidamente de origem europeia.

É importante ressaltar que a Constituição de 1891 seria a primeira Lei Maior a fazer menção ao Supremo Tribunal Militar. O art. 77 previa que os militares de terra e mar teriam

\footnotetext{
${ }^{13}$ D'ARAUJO, Maria Celina. Justiça militar, segurança nacional e tribunais de exceção. In: Encontro Anual da ANPOCS, 30, 2006, Caxambu. Anais... Caxambu: ANPOCS, 2006. Disponível em:

$<$ http://cpdoc.fgv.br/sites/default/files/cfa21/103.pdf $>$. Acesso em: 2 mar. 2018.

${ }^{14}$ Decreto $\mathrm{n}^{\circ} 85-\mathrm{A}$, de 23 de dezembro de 1889.

${ }^{15}$ SODRÉ, Nelson Werneck. A História Militar do Brasil. 3. ed. Rio de Janeiro: Civilização Brasileira, 1979.
} 
foro especial nos delitos militares. Este foro seria o Supremo Tribunal Militar, cujos membros eram vitalícios.

2.3 Da Segunda República: a Revolução de 1930 e a Constituição de 1934

A Revolução de 1930 poria fim à hegemonia da burguesia cafeeira no Brasil. A extinção dessa hegemonia expressa a necessidade de o País reajustar a sua estrutura, "cujo funcionamento, voltado essencialmente para um único gênero de exportação, se torna cada vez mais precário" ${ }^{16}$. Cabe, a propósito, ressalvar que os militares tiveram uma influência marcante no movimento revolucionário. José Murilo de Carvalho assinala, inclusive, que "a primeira república delimita-se pelos parênteses de duas intervenções militares" ${ }^{17}$, ou seja, ela começou, como analisamos anteriormente, com o apoio dos militares e terminou, igualmente, com o suporte destes.

A insatisfação militar, principalmente dos tenentes, e a participação destes na Revolução contribuiriam para um significativo aumento de poder, em especial do Exército, na vida política nacional ${ }^{18}$. Esse aumento de poder aparece de maneira significativa na Constituição de 1934, de modo que as previsões sobre Forças Armadas apareceriam inseridas no Título sobre segurança nacional. Do papel secundário que lhes era atribuído, as Forças Armadas passariam, na década de 1930, a integrar e responder pela segurança nacional do País.

A Constituição de 1934 seria a primeira Constituição brasileira a prever um Título (VI), com nove artigos, sobre segurança nacional. Neste Título, consta que "todas as questões relativas à segurança nacional serão estudadas e coordenadas pelo Conselho Superior de Segurança Nacional e pelos órgãos especiais criados para atender às necessidades da mobilização" 19 . Este Conselho, de acordo com o art.159, era presidido pelo Presidente da República e composto pelos Ministros de Estado, pelo Chefe do Estado-Maior do Exército e o Chefe do Estado-Maior da Armada.

Todas essas modificações revelam-nos a importância que a segurança nacional adquirira no contexto brasileiro, bem como evidencia a participação e a relação militar com a

\footnotetext{
${ }^{16}$ FAUSTO, Boris. A Revolução de 1930: Historiografia e História. 12. ed. São Paulo: Brasiliense, 1989. p. 149.

${ }^{17}$ CARVALHO, José Murilo de. As Forças Armadas na Primeira República: o Poder Desestabilizador. In: FAUSTO, Boris (org.). História Geral da Civilização Brasileira. T. III, v. 2. São Paulo: Difel, 1977. p. 13.

${ }^{18}$ Cf.: CARVALHO, José Murilo de. Forças Armadas e Política, 1930-1945. In: CARVALHO, José Murilo de. Forças Armadas e Política no Brasil. Rio de Janeiro: Jorge Zahar Editor, 2005. p. 62-102.

${ }^{19}$ Art. 159 da Constituição de 1934.
} 
concepção de segurança. O Conselho Superior de Segurança Nacional, assim como os seus órgãos especiais, demonstrariam a preocupação em se pensar uma ideia própria de segurança nacional, através de projeto que atendesse às demandas dessa segurança, que não surgiram com a Guerra Fria, nem tampouco seriam preocupações exclusivas que apareceriam em cena, após a criação da Escola Superior de Guerra, em 1949.

Ademais, a Constituição de 1934 dedicaria uma sessão à Justiça Militar, vinculando-a ao Poder Judiciário. $\mathrm{O}$ art. 84 criava a possibilidade de equiparação de civis a militares, em casos de crime contra a segurança externa do País, ou contra as instituições militares, dotando a Justiça Militar de um caráter de Justiça Especial, caráter este que ficaria mais acentuado com a aprovação da Lei de Segurança Nacional, em 1935.

Todas as mudanças pertinentes às Forças Armadas e à segurança nacional não são, no entanto, fatores, ou circunstâncias, estranhos ao contexto interno ou externo do País. Pelo contrário, elas seriam representativas de diversas transformações que a década de 1930 trouxera ao mundo e, por consequência, ao Brasil. Forças partidárias figurariam naquele momento com uma representatividade nova, tal como o Partido Comunista, criado em 1922, e a Ação Integralista (AI) ${ }^{20}$, instituída em outubro de 1932, que congregaria os adeptos do fascismo.

Surgia, em 23 de março de 1935, a Aliança Nacional Libertadora (ANL), movimento marcadamente antifascista, que congregaria o influxo proveniente das classes médias e de militares insatisfeitos com o rumo do governo Vargas, que, com sua adesão popular, levaria o governo à conclusão de que estaria sendo desenvolvido um golpe, para implantação de um regime comunista.

Dentre os pontos mais importantes do projeto político da ANL, poder-se-ia relacionar o não reconhecimento da dívida externa, a nacionalização dos serviços públicos e a distribuição de terras ${ }^{21}$.

Em contraposição, o governo incentivava as milícias integralistas, para que agregassem influências dos militares e, logicamente, fechassem a Aliança Nacional Libertadora, a partir de medidas de exceção promulgadas pelo Congresso.

Os contornos das condutas militares seriam ampliados e repercutiriam no âmbito jurídico. A participação dos militares, na manutenção da ordem interna, os levaria a atuar na

\footnotetext{
${ }^{20}$ Sobre a AI, cf.: FAUSTO, Boris. Getúlio Vargas: o Poder e o Sorriso. São Paulo: Companhia das Letras, 2006. p. 71-72.

${ }^{21}$ SKIDMORE, Thomas E. Politics in Brazil - 1930 -1964: an Experiment in Democracy. New York: Oxford University Press, 1973. p. 21.
} 
elaboração de leis e nos tribunais de exceção ${ }^{22}$, como é possível verificar pela análise da Segunda República.

\section{O CONTEXTO DA CRIAÇÃO DO TRIBUNAL DE SEGURANÇA NACIONAL}

\subsection{Da promulgação da Lei de Segurança Nacional de 1935}

Foi nesse clima de mobilização social e radicalização ideológica que a Lei de Segurança Nacional ${ }^{23}$, aprovada pelo Congresso, em 4 de abril de 1935, determinaria, como primeiro ato, o fechamento da ANL, em 11 de julho de $1935^{24}$.

O comunismo tratava-se, então, da grande preocupação do governo.

A Lei de Segurança Nacional, apesar do título, não se utilizou da expressão "segurança nacional", nem mesmo previu qualquer tribunal especial, nem citou a Justiça Militar, para julgar qualquer dos crimes nela previstos ${ }^{25}$.

\subsection{Da Intentona Comunista}

A Intentona Comunista foi o nome dado aos levantes ocorridos em Natal, Recife e Rio de Janeiro, em novembro de 1935. Fechada a ANL, muitos que dela participavam resolveram se afastar da política, mas, aqueles que ficariam apostariam na alternativa insurrecional e a colocariam em prática com os levantes em que os militares, especialmente, se destacavam ${ }^{26}$.

Dentre os objetivos dos participantes da Intentona, constavam: "a necessidade de libertação do Brasil da dominação imperialista, o regime de compressão das liberdades democráticas utilizado pelo governo e a diminuição dos efetivos do Exército". ${ }^{27}$

\footnotetext{
${ }^{22}$ LEMOS, Renato. A Questão da Defesa Nacional no Parlamento Brasileiro (1891-1921). In: ARAÚJO, Maria Celina de et al. (orgs.). Defesa, segurança internacional e forças armadas. Campinas: Mercado de Letras, 2008. p. 5 .

${ }^{23}$ Lei $\mathrm{n}^{\circ} 38$, de 4 de abril de 1935.

${ }^{24}$ Decreto $\mathrm{n}^{\circ} 229$, de 11 de julho de 1935.

${ }^{25} \mathrm{O}$ art. 34, por exemplo, prevê que além do militar que cometer quaisquer dos crimes previstos na lei ser afastado do cargo, ele também se tornará incompatível com o oficialato. Ademais, o art. 50 prevê como situação agravante o fato do acusado ser militar.

${ }^{26}$ D'ARAUJO, Maria Celina. Justiça militar, segurança nacional e tribunais de exceção. In: Encontro Anual da ANPOCS, 30, 2006, Caxambu. Anais... Caxambu: ANPOCS, 2006. Disponível em: <http://cpdoc.fgv.br/sites/default/files/cfa21/103.pdf>. Acesso em: 2 mar. 2018. p. 6.

${ }^{27}$ Manifesto dos oficiais que revoltaram o $3^{\circ}$ Regimento de Infantaria, no Rio de Janeiro. In: SODRÉ, Nelson Werneck. A História Militar do Brasil, p. 261-262.
} 
A Intentona Comunista seria severamente abafada e reprimida pelo governo, através das Forças Armadas, dando início a uma luta desenfreada contra o comunismo ${ }^{28}$.

Ainda no decorrer da revolta, seria implantado o Estado de Sítio ${ }^{29}$, convertido em Estado de Guerra pela Emenda Constitucional no 1, vigorando até julho de $1937^{30}$.

Em dezembro de 1935, o governo tornava a Lei de Segurança Nacional ainda mais rigorosa, sob o argumento de que "tal como saiu, podada, do Legislativo, não permitia manter uma ação eficiente," 31 permitindo a demissão de funcionários públicos civis e militares, quando filiados a "partido, centro, agremiação ou junta de existencia prohibida"32.

Seriam promulgadas mais duas Emendas Constitucionais: a Emenda $n^{\circ}$ 2, que permitia que o Executivo cassasse, por decreto, patentes e postos dos militares; e a Emenda $\mathrm{n}^{\mathbf{o}}$ 3, que autorizava o Executivo a exonerar funcionários civis, sem qualquer processo administrativo ou judicial.

Dessa forma, foram criados, no âmbito jurídico, instrumentos cada vez mais repressores, seja alterando a Lei de Segurança Nacional, seja promulgando Emendas Constitucionais, seja decretando o Estado de Guerra. A estrutura para a criação de um tribunal de exceção estava pronta.

\section{O TRIBUNAL DE SEGURANÇA NACIONAL}

\subsection{Da lei do Tribunal de Segurança Nacional}

Nas palavras de Sobral Pinto, em entrevista concedida a Reynaldo Pompeu de Campos: "acontece, porém, que havia uma certa suspeição, o receio de que a justiça não punisse devidamente os autores da revolução de 35 (...) então, à vista disso, o governo resolveu criar um tribunal especial". ${ }^{33}$

\footnotetext{
${ }^{28}$ Cf.: MURICY, Antonio Carlos da Silva. A Guerra Revolucionária no Brasil e o Episódio de Novembro de 1935, p. 41.

${ }^{29}$ O Estado de Sítio foi decretado em 25 de novembro de 1935.

${ }^{30}$ As Emendas Constitucionais $n^{\circ} 1, n^{\circ} 2$ e $n^{\circ} 3$ foram promulgadas em 18 de dezembro de 1935 . A Emenda $n^{\circ} 1$ assim dispunha: "A Câmara dos Deputados, com a colaboração do Senado Federal, poderá autorizar o Presidente da República a declarar a comoção intestina grave com finalidades subversivas das instituições políticas e sociais, equiparada ao Estado de Guerra, em qualquer parte do território nacional observando-se o disposto no art. 175 , n. $1, \S \S 7^{\circ}, 12$ e 13, e devendo o decreto de declaração da equiparação indicar as garantias constitucionais que não ficarão suspensas".

${ }^{31}$ Carta de Vargas a Aranha, 14 de dezembro de 1935. In: SILVA, Hélio. 1937 - Todos os golpes se parecem. Rio de Janeiro: Civilização Brasileira, 1970, p. 106.

${ }^{32}$ Art. $1^{\circ}$ da Lei 136 de 14 de dezembro de 1935.

${ }^{33}$ CAMPOS, Reynaldo Pompeu de. Repressão judicial no Estado Novo, p. 39. Rio de Janeiro: Achiamé, 1982.
} 
A punição para os rebelados não podia ser branda, mas deveria expressar que as Forças Armadas, apesar dos acontecimentos, estavam coesas e agiriam com rigidez contra qualquer um que desafiasse a sua unidade e hierarquia. Dessa forma, a intensa participação militar na criação e atuação do Tribunal de Segurança Nacional não é de se estranhar.

Neste diapasão, seria expedido o Decreto $n^{\circ} 558$, de 31 de dezembro de 1935, que determinava "a perda de patentes e posto de oficiais que participaram do movimento subversivo das instituições políticas e sociais".

O Poder Executivo, então, encaminharia um projeto de lei, para a criação do TSN, conquanto fossem vários de seus artigos considerados inconstitucionais, especialmente sob o argumento de que estariam criando um tribunal de exceção

No dia 12 de setembro de 1936, a Lei $\mathrm{n}^{\circ} 244$ era publicada no Diário Oficial. Na opinião de Adalberto Correia ${ }^{34}$ :

Se antigamente era necessário que as leis protegessem o cidadão contra o Estado, hoje é indispensável que se defenda o Estado contra o indivíduo. Na atualidade, só um organismo de exceção, armado de amplos ou ilimitados poderes poderá opor um dique à avalanche comunista.

\subsubsection{Da lei relativa à criação do Tribunal de Segurança Nacional}

De acordo com o art. $1^{\circ}$ da Lei $n^{\circ} 244$, de 1936, o TSN seria um órgão vinculado à Justiça Militar $^{35}$, com funcionamento apenas no Rio de Janeiro. O TSN ficaria instituído, enquanto vigorasse o estado de guerra e até que ultimasse o processo dos crimes da sua competência. $\mathrm{O}$ art. $2^{\circ}, \mathrm{n}^{\mathrm{o}} 2^{\circ}$, estabelecia que, enquanto funcionasse o TSN, nenhum juiz poderia ser demitido, nem os seus vencimentos reduzidos.

A competência do Tribunal consistia em "processar e julgar em primeira instância os militares, as pessoas que lhe são assemelhadas e os civis" ${ }^{36}$. Os crimes da sua competência eram todos os previstos nas Leis de Segurança Nacional e aqueles considerados conexos ${ }^{37}$. Para os crimes praticados em data anterior à vigência do Tribunal - e que não tivessem sido julgados - foi atribuída a competência, em primeira instância, ao Supremo Tribunal Militar.

\footnotetext{
${ }^{34}$ Discurso de Adalberto Correia. Correio da Manhã. $1^{\text {o }}$ de setembro de 1936. In: CAMPOS, Reynaldo Pompeu de. Repressão judicial no Estado Novo, p. 45.

${ }^{35}$ Art. $1^{\circ}$. Fica instituído, como órgão da Justiça Militar, o Tribunal de Segurança Nacional, que funcionará no Distrito Federal, sempre que for decretado o estado de guerra e até que ultime o processo dos crimes da sua competência.

${ }^{36}$ Art. $3^{\circ}$ da Lei no 244 de 1936.

${ }^{37}$ Art. $3^{\circ}$ e Art. $5^{\circ}$ da Lei no 244 de 1936.
} 
Os processos em andamento na primeira instância deveriam ser remetidos ao Tribunal de Segurança Nacional. Os processos em andamento na segunda instância, ou pendentes de recurso, seriam encaminhados ao Supremo Tribunal Militar ${ }^{38}$, ficando claro dessas medidas a supressão da possibilidade de os processos serem julgados por leis mais liberais.

O Tribunal, tal como prevê o art. $9^{\circ}$, no 19 , não ficava adstrito, no julgamento, à qualificação do crime feito na denúncia, ou seja, o réu poderia ser surpreendido com a condenação de um crime do qual não havia se defendido. As decisões daquela Corte eram tomadas por maioria de votos, cabendo recurso ao Supremo Tribunal Militar, sem efeito suspensivo $^{39}$, caracterizando o TSN como um tribunal de primeira instância. As penas, aplicadas pelo Tribunal, estavam previstas nas Leis de Segurança Nacional, que poderiam ser cumpridas em "colônias agrícolas e penais".

Mesmo que se possa questionar o TSN como um tribunal de exceção, dada a sua vinculação com a Justiça Militar, ele, certamente, foi inconstitucional, por violar o art. 103, $\mathrm{n}^{\circ}$ 25, da Constituição de 1934, que prevê a retroatividade da lei apenas para beneficiar o réu. No mesmo sentido, o direito de defesa, consagrado na Constituição, "foi mutilado por múltiplos expedientes e os recursos e meios essenciais para o seu exercício passavam à categoria de favores, cuja recusa ou outorga dependiam da vontade dos juízes" ${ }^{40}$.

O TSN, como órgão da Justiça Militar, devido à hibridez da sua composição, demonstrava a integração dos militares, a sua intensa participação e repercussão no âmbito jurídico.

Ocorre que a atuação dos militares poderia ser considerada sem suporte constitucional, na medida em que intervinham no âmbito jurídico, processavam e julgavam civis, enquanto a competência para julgamento já estava definida anteriormente como sendo da Justiça Comum. A participação militar acabava, portanto, por ser repressora e arbitrária, justamente porque alterava as leis e a Constituição, quando assim lhe fosse conveniente.

\footnotetext{
${ }^{38}$ Art. $4^{\text {o }}$ da Lei $n^{\circ} 244$ de 1936.

${ }^{39}$ Art. 10 da Lei no 244 de 1936.

${ }^{40}$ CAMPOS, Reynaldo Pompeu de. Repressão judicial no Estado Novo, p. 50.
} 
4.2 A primeira fase: julgando os revoltosos da Intentona Comunista

O primeiro processo recebido pelo TSN foi também o mais célebre, visto que tratava dos envolvidos na Intentona Comunista, como Prestes e os demais líderes da $\mathrm{ANL}^{41}$. O processo $\mathrm{n}^{\mathrm{o}} 1$ continha 41 volumes, arrolava 36 pessoas consideradas diretamente responsáveis pelo Levante e mais 120 indiciados ${ }^{42}$. O procedimento da audiência era composto por três fases: relatório, sessão secreta e sentença.

No dia 28 de julho de 1937, o TSN julgaria os co-réus Luis Carlos Prestes, condenado a 16 anos e 8 meses de reclusão e Harry Berger, a 13 anos e 4 meses de reclusão. A maior pena coube a Agilberto Vieira de Azevedo, que somou 27 anos e 6 meses de reclusão ${ }^{43}$, por ter sido acusado de homicídio, sendo-lhe aplicado, além da Lei de Segurança Nacional, o Código Penal Militar.

Segundo as sentenças, proferidas no processo $\mathrm{n}^{\circ} 1$ do TSN, os crimes mais recorrentes eram os previstos no art. $1^{\circ}$, art. $4^{\circ}$ e art. 49 da Lei $n^{\circ} 38$, de 1935 , cuja importância recomenda a transcrição abaixo:

Art. $1^{\circ}$ Tentar directamente e por facto, mudar, por meios violentos, a Constituição da Republica, no todo ou em parte, ou a forma de governo por ella estabelecida. Pena - Reclusão por 6 a 10 annos aos cabeças e por 5 a 8 aos co-réus.

Art. $4^{\circ}$ Será punido com as mesmas penas dos artigos anteriores, menos a terça parte, em cada um dos gráos, aquelle que, para a realização de qualquer dos crimes definidos nos mesmos artigos, praticar algum destes actos: alliciar ou articular pessoas; organizar planos e plantas de execução; apparelhar meios ou recursos para esta; formar juntas ou commissões para direcção, articulação ou realização daquelles planos; installar ou fazer funcionar clandestinamente estações radio-transmissoras ou receptoras; dar ou transmittir, por qualquer meio, ordens ou instrucções para a execução do crime.

Art. 49. Reputam-se cabeças os que tiverem deliberado, excitado ou dirigido a pratica de actos punidos nesta lei.

Apesar de o julgamento ter ocorrido em maio de 1937, a maior parte dos acusados estava preso desde o final de 1935. Harry Berger, por exemplo, foi preso em dezembro de 1935, torturado, e só foi libertado em junho de 1947, sem jamais conseguir recuperar sua

\footnotetext{
41 "O Tribunal de Segurança Nacional (TSN), destinado a julgar sumariamente os presos políticos, começou a funcionar em setembro de 1936. Os condenados, cuja chance de defesa era bastante escassa, eram enviados principalmente para a Colônia Correcional de Dois Rios, na Ilha Grande e, mais tarde, para Fernando de Noronha. Uma caçada sem trégua foi lançada contra Prestes e os "agentes de Moscou" no Distrito Federal, destacando-se nessa missão, entre outras figuras sinistras, a do chefe de polícia Filinto Müller (...)”. FAUSTO, Boris. Getúlio Vargas - o Poder e o Sorriso, p. 76-77.

${ }^{42}$ Sobre o processo $n^{\circ} 1$, Cf.: CAMPOS, Reynaldo Pompeu de. Repressão judicial no Estado Novo, p. 54-70.

${ }^{43}$ CAMPOS, Reynaldo Pompeu de. Repressão judicial no Estado Novo, p. 54-55.
} 
saúde psíquica ${ }^{44}$. Sobral Pinto, advogado de Harry Berger, chegou a fazer uma petição, com base no artigo 14 da Lei de Proteção aos Animais, requerendo um tratamento mais humano para o preso. ${ }^{45}$ Victor Barron não chegou a ser julgado, pois morreu no curso dos interrogatórios policiais, após ser jogado de uma das janelas da Polícia Central, já morto, mas dado pela polícia de Filinto Müller como suicida ${ }^{46}$.

Olga Benário, mulher de Luís Carlos Prestes, foi entregue à Gestapo, antes mesmo do Estado Novo. Grávida de sete meses, enfrentou uma viagem de navio à Alemanha, deu à luz a sua filha, em uma prisão da Gestapo, e morreu em uma câmara de gás no campo de Berburg, em abril de $1942^{47}$. As torturas tornaram-se frequentes, como parte do procedimento policial da época, atingindo notórios comunistas, ou simples e desconhecidos suspeitos ${ }^{48}$. Graciliano Ramos, em “Memórias do Cárcere”, relata as barbaridades cometidas, à época, por essa Corte de exceção. ${ }^{49}$

Como o estado de sítio estava comparado ao estado de guerra, as imunidades parlamentares estavam extintas, abrindo-se a possibilidade de se prenderem diversos parlamentares. No julgamento de segunda instância, preso há mais de um ano, João Mangabeira teve a sentença que o condenara anulada e Octávio da Silveira a pena diminuída de três anos para seis meses.

No meio universitário, os professores foram perseguidos, as bibliotecas "purificadas" e determinados livros queimados em praça pública ${ }^{50}$. Alzira Vargas do Amaral Peixoto relata, em relação aos professores ${ }^{51}$ :

um certo mistério envolvia os fatos (...). Foram presos sob a acusação de comunistas e mais nada. De nossa Faculdade eram quatro: Edgard Castro Rabelo, catedrático de Direito Comercial (...); Leônidas de Rezende, catedrático da Economia Política; Hermes Lima, catedrático de Intodução à Ciência do Direito e Carpenter Ferreira, catedrático de Direito Judiciário Penal.

Perguntando ao pai, Getúlio Vargas, sobre a prisão dos professores, Alzira Vargas relata a resposta recebida ${ }^{52}$ :

\footnotetext{
${ }^{44}$ FAUSTO, op. cit., p.77.

${ }^{45}$ CAMPOS, Reynaldo Pompeu de. Repressão judicial no Estado Novo, p. 60.

${ }^{46}$ FAUSTO, Boris. Getúlio Vargas - o Poder e o Sorriso, p.77.

${ }^{47}$ Ibidem, loc. cit.

${ }^{48}$ Sobre as torturas cometidas nesse período por policiais e militares, Cf.: O Mundo da Violência - A Polícia da Era Vargas. $2^{a}$ Edição. Brasília: Editora Universidade de Brasília, 1994.

${ }^{49}$ RAMOS, Graciliano. Memórias do Cárcere. 4. ed. São Paulo: Martins, 1960.

${ }^{50}$ SODRÉ, Nelson Werneck. A História Militar do Brasil, p. 259.

${ }^{51}$ Ibidem, p. 259-260.

${ }^{52}$ Ibidem, p. 260.
} 
Foi uma exigência dos chefes militares. Consideravam uma injustiça serem punidos os oficiais presos de armas na mão, enquanto os instigadores de tudo, os intelectuais que pregavam as ideias subversivas, continuavam em liberdade. Foi alegado em favor da prisão imediata o fato de se utilizarem da cátedra, da pena e da imprensa para instilarem o comunismo na cabeça não suficientemente amadurecida dos jovens. Eram muito mais perniciosos do que aqueles que combateram.

Embora os professores tenham sido detidos, não foram processados. De fato, durante a repressão policial haviam sido presas cerca de seis mil pessoas, mas muitas delas não responderam criminalmente. Algumas foram libertadas, mediante impetração de habeas corpus. Outras, pela intervenção do Ministro da Justiça, José Carlos de Macedo Soares, que, após visitar as prisões, ordenou a libertação de muitos detentos, contra os quais nada havia sido apurado.

\begin{abstract}
Assim como eram milhares os detentos sem processo formal, também os presos só eram libertados com a anuência da polícia, consultada a Delegacia Especial de Ordem Política e Social. São muitos os telegramas vindos dos diversos presídios do país e enviados ao Ministério da Justiça, consultando sobre a conveniência ou não de liberar presos. O TSN emitia o alvará de soltura, mas este não era encaminhado aos presídios $^{53}$.
\end{abstract}

Cabe ressalvar que, de acordo com as Leis de Segurança Nacional, os crimes tipicamente militares continuavam a ser julgados pela Justiça Militar (sem o TSN). Lembre-se que o TSN era competente para julgar os crimes cometidos por militares previstos nas Leis de Segurança Nacional. Sendo a Intentona Comunista um movimento principalmente composto por militares, o governo estava preocupado "em expurgar o Exército de suas vozes dissidentes" ${ }^{54}$. Nas palavras de Góis Monteiro: "era preciso acabar com a política no Exército e impor a política do Exército". 55

De fato, o TSN, criado para julgar e condenar comunistas, com a maior celeridade possível, cumpriu muito bem o seu papel. Ao final de 1937, o TSN já havia julgado todos os alegadamente responsáveis e cúmplices da Intentona. Uma nova fase, no entanto, estava prestes a começar.

\footnotetext{
${ }^{53}$ CANCELLI, Elizabeth. O mundo da violência, p. 210. $2^{\text {a }}$ Ed. Brasília: Universidade de Brasília, 1994.

${ }^{54}$ D'ARAUJO, Maria Celina. Justiça Militar, Segurança Nacional e Tribunais de Exceção, p. 8.

${ }^{55}$ Ibidem, p. 8.
} 
4.3 A segunda fase: o Tribunal de Segurança Nacional durante o Estado Novo

O comunismo, após a Intentona de 1935, passou a ser o principal inimigo interno, violentamente combatido pela polícia, pela cúpula militar e pelo governo. Apesar de toda a propaganda criada contra os comunistas, era preciso que ocorresse um evento capaz de estimular e legitimar definitivamente uma ditadura. Esse evento foi chamado de Plano Cohen, um documento cujo conteúdo projetava um plano de golpe de Estado comunista. Na verdade, o seu autor, o Capitão Olímpio Mourão Filho, chefe do serviço secreto integralista, pretendia criar, como hipótese de trabalho, um plano comunista ${ }^{56}$. O Presidente do Supremo Tribunal Militar, General Álvaro Mariante, ficou bastante interessado no documento e, em 30 de setembro de 1937, a Casa Militar da Presidência da República publicou uma nota em todos os jornais, anunciando a descoberta de um tenebroso plano comunista, elaborado pelo Comintern $^{57}$. Não houve, então, qualquer dificuldade para que, no dia 10 de novembro de 1937, fossem fechadas as duas Casas do Congresso, dando início ao Estado Novo.

A Carta de 1937, redigida pelo jurista Francisco Campos, atenderia "ao estado de apreensão criado no País pela infiltração comunista, que se tornava, dia a dia, mais perigosa, exigindo remédios de caráter radical e permanente" ${ }^{58}$. A Carta não citava o TSN. Dedicava, no entanto, um capítulo à "Segurança Nacional" e outro à "Defesa do Estado", transparecendo uma série de ameaças possíveis para o Brasil. A previsão do art. 166 era exemplificativa, ao tratar de "ameaça externa ou iminência de perturbações internas ou existências de concerto, plano ou conspiração, tendente a perturbar a paz pública ou pôr em perigo a estrutura das instituições, a segurança do Estado ou dos cidadãos”.

As normas, atribuindo competência às Forças Armadas e ao Conselho de Segurança Nacional, estavam inseridas no capítulo "Da Segurança Nacional”. O capítulo sobre a "Defesa do Estado" tratava do Estado de Guerra e do Estado de Emergência.

Os artigos, citados acima, revelam a intensa preocupação com a segurança nacional, a defesa da pátria e das instituições. Essa preocupação repercutiria nas Leis de Segurança Nacional, ocasionando radicais modificações.

\footnotetext{
${ }^{56}$ Sobre o Plano Cohen, Cf.: FAUSTO, Boris. Getúlio Vargas - o Poder e o Sorriso, p.79.

${ }^{57}$ Sobre o golpe de 1937 e o Plano Cohen, Cf.: SILVA, Hélio. 1937 - Todos os golpes se parecem.

${ }^{58}$ Preâmbulo da Carta de 1937.
} 
Cabe destacar que, assim como nos movimentos anteriores, supracitados, as Forças Armadas, em especial o Exército, tiveram um papel decisivo na sustentação do Estado Novo, até que a conjuntura dos anos 1944-1945 levasse à deposição do Presidente ${ }^{59}$.

\subsubsection{Do Decreto-Lei $n^{o}$ 88, de 20 de dezembro de 1937}

O Decreto-Lei $\mathrm{n}^{\circ}$ 88, de 20 de dezembro de 1937, transformava o TSN em órgão autônomo, desligado, portanto, da Justiça Militar, não mais atuando como órgão de segunda instância.

$\mathrm{O}$ art. $2^{\circ}$ do Decreto-Lei previa o aumento dos componentes do TSN, de cinco para seis juízes, composto por um magistrado civil, um magistrado militar, um oficial do Exército, um da Armada e um advogado de notória competência jurídica.

O Decreto-Lei inovou quanto aos crimes da competência do TSN, prevendo, no art. $4^{\circ}$, além daqueles estabelecidos nas Leis de Segurança Nacional, os crimes contra a economia popular ${ }^{60}$. Competia ainda ao TSN, segundo o parágrafo único do art. $4^{\circ}$, “conhecer e decidir sobre habeas corpus impetrado em favor de quem sofra ou se ache ameaçado de sofrer violência ou coação, por ilegalidade ou abuso de poder, em virtude de ato ou fato que lhe seja atribuído como crime de competência do Tribunal".

O procedimento adotado previa que cada processo fosse encaminhado a um juiz que proferiria a sentença ${ }^{61}$. Sendo o réu condenado, havia a possibilidade de apelação para o Tribunal Pleno, composto de mais cinco juízes, ficando o juiz que proferiu a sentença impedido de julgar o recurso ${ }^{62}$. Caso o réu fosse absolvido, o juiz que proferira a sentença era obrigado a apelar ex officio da sua própria sentença ${ }^{63}$. O número de testemunhas arroladas pela defesa foi reduzido de cinco para três, não sendo admitidos debates orais ${ }^{64}$. As sentenças, além de irrecorríveis, não poderiam ser suscetíveis de embargo. Todos os julgamentos eram secretos ${ }^{65}$.

\footnotetext{
${ }^{59}$ FAUSTO, Boris. Getúlio Vargas - o Poder e o Sorriso, p.89.

${ }^{60}$ O Decreto-Lei ${ }^{\circ} 869$, de 18 de novembro de 1938, define os crimes contra a economia popular.

${ }^{61}$ Art. $7^{\circ}$ do Decreto-Lei no 88 de 1937.

${ }^{62}$ Art. $8^{\circ}$ do Decreto-Lei no 88 de 1937.

${ }^{63}$ Art. $8^{\circ}$, parágrafo único, do Decreto-Lei no 88 de 1937.

${ }^{64}$ Art. 20, no 13, do Decreto-Lei no 88 de 1937.

${ }^{65}$ Art. 12 do Decreto-Lei no 88 de 1937.
} 
4.3.2 Da "Fase Verde": julgando os integralistas

Outra modificação importante na legislação do TSN ocorreu após o putsch integralista, de 11 de maio de 1938. O integralismo teve seu campo livre após a Intentona e seus mentores almejavam receber a parcela de poder que lhes competia, em troca do apoio que ofereceram a Vargas e ao Estado Novo. Era esperado que Plínio Salgado fosse nomeado Ministério da Educação e que a AIB tivesse ampla liberdade de influência ${ }^{66}$. Não foi, contudo, o que aconteceu. A organização foi extinta, junto com os demais partidos políticos ${ }^{67}$. A maioria resignou-se, mas um setor, no qual se destacou o médico Belmiro Valverde, partiu para o ataque ao governo. Otávio Mangabeira, Severo Fournier, Flores da Cunha, Lindolfo Collor, General Guedes da Fontoura foram algumas das personalidades que se uniram aos integralistas, para tentar tirar Vargas do poder. O alvo principal foi o Palácio da Guanabara, onde se encontravam Vargas e sua família. O putsch fracassou e a repressão policial foi implacável.

Após a tentativa de depor o Presidente, cerca de 1500 pessoas foram detidas ${ }^{68}$. No dia 16 de maio de 1938, foi expedido o Decreto-Lei $n^{\circ} 428$, alterando novamente o procedimento do Tribunal. O número de testemunhas foi reduzido a duas para cada réu ${ }^{69}$. As testemunhas eram interrogadas por cinco minutos cada, a acusação falava por quinze minutos, a defesa por igual tempo e meia hora depois era proferida a sentença ${ }^{70}$. Se todos os prazos fossem cumpridos, entre o recebimento do inquérito e o julgamento, não decorreriam mais do que cinco dias.

Dois dias depois, em 18 de maio de 1938, o Decreto-Lei $\mathrm{n}^{\circ} 431$ era expedido, definindo "os crimes contra a personalidade internacional, a estrutura e a segurança do Estado e contra a ordem social.” Era uma nova Lei de Segurança Nacional e, entre outras medidas, instituía, no art. $2^{\circ}$, a pena de morte ${ }^{71}$.

\footnotetext{
${ }^{66}$ FAUSTO, Boris. Getúlio Vargas - o Poder e o Sorriso, p.136.

${ }^{67}$ Decreto-Lei no 37 de 2 de dezembro de 1937.

${ }^{68}$ CAMPOS, Reynaldo Pompeu de. Repressão judicial no Estado Novo, p. 89.

${ }^{69}$ Art. $6^{\circ}, \S 1^{\circ}$, do Decreto-Lei ${ }^{\circ} 428$ de 1938.

${ }^{70}$ Art. $6^{\circ}$ do Decreto-Lei no 428 de 1938.

${ }^{71}$ Art. $2^{\circ}$ Caberá pena de morte nos seguintes crimes: 1) tentar submeter o território da Nação, ou parte dele, à soberania de Estado estrangeiro; 2) atentar, com auxílio ou subsídio de Estado estrangeiro ou organização de carater internacional, contra a unidade da Nação, procurando desmembrar o território sujeito à sua soberania; 3) tentar por meio de movimento armado o desmembramento do território nacional, desde que para reprimí-lo se torne necessário proceder a operações de guerra; 4) tentar, com auxílio ou subsídio de Estado estrangeiro ou organização de carater internacional, a mudança da ordem política ou social estabelecida na Constituição; 5) tentar subverter por meios violentos a ordem política e social, com o fim de apoderar-se do Estado para o estabelecimento da ditadura de uma classe social; 6) insurreição armada contra os poderes do Estado, assim
} 
Embora o procedimento continuasse o mesmo, ainda em 1938, o Decreto-Lei $\mathrm{n}^{\mathrm{o}} 474$, de 8 de junho, estabelecia novos prazos processuais, de modo que, se todos os prazos fossem cumpridos, a sentença seria prolatada em até oito dias.

Em setembro do mesmo ano, começaram os julgamentos. Os processos mais importantes eram os de $n^{\circ} 600$ e 606 , uma vez que envolviam as principais figuras. As penas aplicadas eram mais severas e as condições de defesa piores do que as enfrentadas pelos comunistas. Se o STM, quando funcionava como segunda instância, diminuía as penas, o Tribunal Pleno as aumentava, inclusive, condenando quem, em primeira instância, havia sido absolvido. Belmiro Valverde fora condenado, em primeira instância, a oito anos de reclusão e o Pleno aumentou a pena para 10 anos; General Castro Junior fora absolvido em primeira instância e condenado a um ano e nove meses pelo Pleno; Lauro Antunes, Oswaldo Belém e Antonio Correia da Silva foram, primeiramente, condenados a 1 ano de reclusão, enquanto o Pleno reformou as sentenças para 3 anos e 4 meses para cada um. Apenas Euclydes Figueiredo conseguiu diminuir sua pena ${ }^{72}$.

No processo $\mathrm{n}^{\circ} 538$, foram condenadas 109 pessoas, com penas que variavam entre 5 e 8 anos; no processo $\mathrm{n}^{\circ} 595$, foram condenadas 95 pessoas, com penas que variavam entre 2 e 4 anos; no processo $\mathrm{n}^{\circ} 585,15$ pessoas foram condenadas a penas entre 3 e 8 anos. A maior pena dada, na história do Tribunal, coube ao sargento Luiz Gonzaga de Carvalho, condenado a 40 anos de prisão, por ter assassinado um membro da guarda palaciana ${ }^{73}$.

\subsubsection{A atuação do Tribunal de Segurança Nacional após o putsch integralista}

O Estado Novo propiciou denúncias sem motivação, arbítrios, perseguições e torturas. Nas Forças Armadas, era rigorosa a vigilância sobre oficiais e sargentos ${ }^{74}$. A criação do Tribunal de Segurança Nacional, em 1936, abria caminho para os eventos que se seguiriam. Inúmeras casas foram revistadas sem permissão judicial, inúmeras pessoas presas sem a

\footnotetext{
considerada ainda que as armas se encontrem em depósito; 7) praticar atos destinados a provocar a guerra civil, si esta sobrevem em virtude deles; 8) praticar devastação, saque, incêndio, depredação ou quaisquer atos destinados a suscitar terror, com o fim de atentar contra a segurança do Estado e a estrutura das instituições; 9) atentar contra a vida, a incolumidade ou a liberdade do Presidente da República. § $1^{\circ} \mathrm{A}$ pena de morte, nos casos dos incisos $1^{\circ}$ a $7^{\circ}$, será aplicada aos cabeças; aos demais, pena de prisão por trinta anos. $\S 2^{\circ}$ Nos casos dos incisos $8^{\circ}$ e $9^{\circ}$, a pena de morte será aplicada aos autores como aos cúmplices. $\S 3^{\circ} \mathrm{A}$ pena de morte será executada por fuzilamento em uma das prisões do Estado, designada pelo ministro da Justiça e Negócios Interiores. A menos que este determine o contrário, a execução não será pública.

${ }_{72}^{72}$ CAMPOS, Reynaldo Pompeu de. Repressão judicial no Estado Novo, p. 90-99.

${ }^{73}$ Ibidem, p. 90-99.

${ }^{74}$ Cf.: SODRÉ, Nelson Werneck. A História Militar do Brasil, p. 281-282.
} 
existência de prova concreta, inúmeros presos, apesar de cumprirem integralmente as penas, não eram colocados em liberdade.

Luís Carlos Prestes foi novamente julgado, acusado do assassinato da jovem Elza Fernandes. ${ }^{75}$ Quando Prestes foi preso, em 1936, a polícia apreendeu em sua casa diversas cartas trocadas entre ele e alguns companheiros. O conteúdo das mensagens girava em torno de Elza. O caso só foi reaberto em julho de 1940, embora as cartas tivessem sido apreendidas em 1936. O advogado de Prestes, Sobral Pinto, alegou a incompetência do TSN para julgar o caso, já que se tratava de um homicídio “comum”, sem qualquer vínculo com a segurança nacional. O TSN não considerou as colocações feitas pela defesa e Prestes foi condenado a 30 anos de prisão, sem nunca reconhecer a autoria das cartas.

Como a maior preocupação do Tribunal girava em torno dos comunistas, qualquer fato levava o suspeito a julgamento. Em Fortaleza, algumas pessoas resolveram arrecadar fundos para ajudar as Forças Armadas. Colocaram, então, em uma praça da Cidade, uma pirâmide chamada Stalingrado, já que a URSS, naquele momento, estava ao lado dos Aliados. Não foi, contudo, o entendimento oficial, ensejando em denúncia, em cujo julgamento o denunciado fora condenado.

Os comunistas e integralistas não foram, contudo, os únicos julgados pelo TSN. Gilberto Freyre, em 9 de junho de 1942, publicou um artigo no "Diário de Pernambuco”, denunciando uma pregação racista feita por um padre, responsável pela direção espiritual de escoteiros. Além da proibição de publicar o seu artigo, Gilberto Freyre foi preso em sua casa e enviado à Casa de Detenção do Recife. No dia seguinte, foi solto, a pedido do Ministro de Guerra, Góis Monteiro, mas, dois anos mais tarde, não escaparia de uma denúncia feita no $\mathrm{TSN}^{76}$.

Monteiro Lobato escreveu uma carta a Getúlio Vargas, condenando a política do governo em relação ao petróleo. Para Lobato, o governo não estava favorecendo as indústrias nacionais, mas tão somente empresas estrangeiras, como a Shell, por exemplo. Vargas enviou a carta ao Presidente do CNP (Conselho Nacional do Petróleo), General Júlio Horta Barbosa, que, ofendido pelas afirmações de Monteiro Lobato, fez a denúncia ao TSN. O juiz, Maynard Gomes, absolveu, mas, o Pleno, em grau recursal, condenou Lobato a seis meses de prisão ${ }^{77}$.

\footnotetext{
${ }^{75}$ Processo TSN n ${ }^{\circ}$ 1381. In: CAMPOS, Reynaldo Pompeu de. Repressão judicial no Estado Novo, p. 99-107.

${ }^{76}$ FONSECA, Edson Nery da. Recepção de Casa Grande e Senzala no Recife dos anos 30 e 40 . In: Gilberto Freyre em quatro tempos, p. 33. São Paulo: Unesp, 2003.

${ }^{77}$ Processo TSN no 1607. In: CAMPOS, Reynaldo Pompeu de. Repressão judicial no Estado Novo, p. 113.
} 
A legislação relativa ao TSN só foi modificada em outubro de 1942, após a entrada do Brasil na $2^{\mathrm{a}}$ Guerra Mundial. O Decreto-Lei $\mathrm{n}^{\mathrm{o}} 4766$, de $1^{\circ}$ de outubro, tinha por objetivo a atuação dos militares ${ }^{78}$. Os crimes, previstos no Decreto-Lei, pretendiam abarcar situações de um País em guerra, expandindo a competência do TSN para incluir os crimes de espionagem $^{79}$. De resto, a competência seria da Justiça Militar. Cabe ressaltar que, durante a guerra, duas auditorias militares funcionaram na Itália.

Na medida em que os opositores do regime, fossem eles comunistas, ou integralistas, se encontravam processados e julgados, o TSN passou a desempenhar outro papel: julgar os crimes contra a economia popular.

\subsubsection{TSN e os crimes contra a economia popular}

O TSN passou a julgar crimes contra a economia popular, após julgar os integralistas.

Nilo Lopes Pinheiro, empregado em um armazém no Rio de Janeiro, fora indiciado por ter vendido um quilo de erva-mate por um preço acima da tabela oficial ${ }^{80}$. Luiz Caetano, farmacêutico, em Jundiaí, fota condenado a seis meses de prisão, sendo-lhe aplicada multa, por ter vendido remédios "a preços exorbitantes, em hora avançada da noite" ${ }^{81}$. José Lenório Rodrigues, açougueiro, vendera 500 gramas de carne a um cliente, quando um policial, próximo no momento, desconfiara do peso da carne e determinara que a carne fosse novamente pesada. Como a balança pesou 450 gramas de carne, José Lenório Rodrigues foi preso em flagrante e mantido preso por um mês, até ser absolvido.

Em 1944, com a guerra chegando ao fim, os sintomas de derrocada do Estado Novo começavam a se anunciar. O movimento pela anistia dos presos políticos levava multidões às ruas. No dia 18 de abril de 1945, a anistia era decretada, libertando 563 presos políticos. ${ }^{82} \mathrm{~A}$ liberdade de imprensa foi alcançada e novos rumos se abriam em direção à liberdade dos indivíduos, em consonância com o novo clima mundial. No dia 29 de outubro de 1945, Vargas era deposto por um golpe militar.

\footnotetext{
${ }^{78}$ Por exemplo: Art. $2^{\circ}$. Exercer coação contra oficial general, ou comandante de unidade, mesmo que não seja superior, com o fim de impedir-lhe o cumprimento de dever militar. Pena: reclusão de três a seis anos, se o fato não constituir crime mais grave. Art. $3^{\circ}$. Aliciar militar a passar-se para o inimigo; ou libertar prisioneiros. Pena: morte, grau máximo; reclusão por vinte anos, grau mínimo.

${ }^{79}$ Dentre os crimes de espionagem previstos na lei: Art. 46. Conseguir, para o fim de espionagem política ou militar, documento, notícia ou informação que, no interesse da segurança do Estado, ou no interesse político, interno ou internacional do Estado, deva permanecer secreto. Pena: reclusão de oito a vinte anos.

${ }^{80}$ Processo no 1037. In: CANCELLI, Elizabeth. O Mundo da Violência - A Polícia da Era Vargas, p. 106.

${ }^{81}$ Processo no 952. In: CANCELLI, Elizabeth. O Mundo da Violência - A Polícia da Era Vargas, p. 107.

${ }^{82}$ Decreto - lei n 7.474 de 18 de abril de 1945.
} 
Quase um mês após a deposição de Vargas, o TSN era extinto, através da Lei $n^{\circ} 14$, de 17 de novembro de 1945. Durante oito anos, onze meses e dezessete dias, julgou 6998 processos, que envolviam mais de 10.000 pessoas, nas quais 4.099 foram condenadas a penas que variavam entre uma multa até 60 anos de reclusão ${ }^{83}$.

Com o fim do Estado Novo, caberia ao STM julgar os crimes, praticados por civis e militares, contra a segurança externa do País. A justiça comum ficaria responsável pelos crimes contra a segurança nacional e a economia popular

\section{CONCLUSÃO}

O Tribunal de Segurança Nacional caracteriza-se como uma nódoa na história jurídica brasileira. A atuação do TSN, seja com a presença de juízes militares, seja na própria criação do Tribunal, revelou a efetiva participação militar no âmbito jurídico, mesmo que o objetivo incluísse processar e julgar civis.

O Tribunal em apreço revela também que, mesmo nos regimes autoritários, o direito serve de suporte, atuando como instrumento, muitas vezes, de repressão. A intensa produção legal, envolvendo a segurança nacional, bem como os procedimentos do TSN demonstram a intensa necessidade de se manterem as leis constantemente atualizadas, com relação às possíveis ameaças que surgissem, ainda que sem respaldo constitucional.

Naquele momento, a responsabilidade para julgar crimes contra a segurança do Estado esteva vinculada tanto ao Poder Executivo como aos seus principais chefes militares, que passaram a atuar, decisivamente, em defesa da segurança nacional. Evidentemente que não coube somente à instituição militar, nem ao Judiciário, zelar pela segurança nacional. Todo um aparelhamento do Estado foi feito através de leis e legislação infraconstitucional, pouco importando a constitucionalidade destas.

Ocorre que, nos anos 1930, ao contrário do período da Ditadura Militar (1964-1985), a Justiça Militar estava ainda pouco preparada para enfrentar institucionalmente situações que envolvessem civis e militares. Era necessário que houvesse uma maior homogeneização ideológica e política, que viria com a Ditadura Militar e com a Escola Superior de Guerra.

A própria concepção de segurança nacional foi transformada ao longo do tempo, desenvolvendo-se como doutrina durante a Guerra Fria. É, no entanto, interessante notar que,

\footnotetext{
${ }^{83}$ Dados fornecidos por: CAMPOS, Reynaldo Pompeu. Repressão judicial no Estado Novo, p. 123.
} 
já nos anos 1930 e 1940, diversas bases estavam lançadas para o crescimento da atuação militar na política, marcada, profundamente, em questões de Estado. Ademais, o crescimento da influência militar na política ajuda-nos a compreender como as Forças Armadas estavam relacionadas com um projeto autoritário, que se desenvolveu definitivamente com a Ditadura Militar de 1964.

O TSN, na sua atuação, cooperou para um verdadeiro delírio anticomunista, julgando suspeitos de discordar do regime então vigente. O pavor do comunismo empolgou tanto o governo como boa parte do setor militar, de modo que o próprio conceito de comunismo se tornou vulgarizado e confuso. A intolerância, a condenação contra as evidências dos autos, a perseguição e a repressão marcaram as ações do TSN.

Criado com o objetivo de julgar os responsáveis pela Intentona, o TSN mostrou-se um instrumento que serviu ao combate aos inimigos políticos de todas as correntes, mas, de forma inconstitucional, espelhando uma triste página na história jurídica brasileira.

\section{REFERÊNCIAS}

ALVES, Maria Helena Moreira. Estado e Oposição no Brasil (1964-1984). 3. ed. Rio de Janeiro: Vozes, 1985.

ARQUIDIOCESE DE SÃO PAULO. Brasil: nunca mais, 8. ed. Rio de Janeiro: Vozes, 1985.

CAMPOS, Reynaldo Pompeu de. Repressão Judicial no Estado Novo: Esquerda e Direita no Banco dos Réus. Rio de Janeiro: Achiamé, 1982.

CANCELLI, Elizabeth. O Mundo da Violência: A Polícia da Era Vargas. Brasília: UNB, 1993.

CARVALHO, José Murilo de. Forças Armadas e Política no Brasil. Rio de Janeiro: Jorge Zahar Editor, 2005.

CERQUEIRA, Marcello. A Constituição na História: Origem e Reforma. Rio de Janeiro: Revan, 1993.

COELHO, Edmundo Campos. Em Busca de Identidade: o Exército e a Política na Sociedade Brasileira. Rio de Janeiro: Forense Universitária, 1976.

COMBLIN, Joseph. A Ideologia da Segurança Nacional: o Poder Militar na América Latina. 3. ed. Rio de Janeiro: Civilização Brasileira, 1980.

D’ARAUJO, Maria Celina. Justiça militar, segurança nacional e tribunais de exceção. In: Encontro Anual da ANPOCS, 30, 2006, Caxambu. Anais... Caxambu: ANPOCS, 2006. 
Disponível em: $<$ http://cpdoc.fgv.br/sites/default/files/cfa21/103.pdf $>$. Acesso em: 2 mar. 2018.

FAUSTO, Boris. A Revolução de 1930: Historiografia e História. 12. ed. São Paulo: Brasiliense, 1989.

FAUSTO, Boris (org.). História Geral da Civilização Brasileira. T. III, v. 2. São Paulo: Difel, 1977.

FAUSTO, Boris. Getúlio Vargas: o Poder e o Sorriso. São Paulo: Companhia das Letras, 2006.

FONSECA, Edson Nery da. Recepção de Casa Grande e Senzala no Recife dos anos 30 e 40. In: KOSMINSKY, Ethel Volfzon (org.), LÉINE, Claude (org.), PEIXOTO, Fernanda Arêas (org.). Gilberto Freyre em quatro tempos. São Paulo: Editora Unesp, 2003. pp. 29-41.

LEMOS, Renato. A Questão da Defesa Nacional no Parlamento Brasileiro (1891-1921). In: ARAÚJO, Maria Celina de et al. (orgs.). Defesa, segurança internacional e forças armadas. Campinas: Mercado de Letras, 2008.

MAXIMILIANO, Carlos. Commentarios à Constituição Brasileira. 3. ed. Porto Alegre: Livraria do Globo, 1929.

MURICY, Antonio Carlos da Silva. A Guerra Revolucionária no Brasil e o Episódio de Novembro de 1935. Natal: Instituto Histórico e Geográfico do Rio Grande do Norte, 1966.

PESSOA, Mário. O Direito da Segurança Nacional. Rio de Janeiro: Biblioteca do Exército; Revista dos Tribunais, 1971.

RAMOS, Graciliano. Memórias do Cárcere. 4. ed. São Paulo: Martins, 1960.

SKIDMORE, Thomas E. Politics in Brazil-1930 -1964: an Experiment in Democracy. New York: Oxford University Press, 1973.

SILVA, Hélio. O Poder Militar. 2. ed. Porto Alegre: L\&PM Editores, 1985.

SILVA, Hélio. 1937: Todos os Golpes se Parecem. Rio de Janeiro: Civilização Brasileira, 1970.

SODRÉ, Nelson Werneck. A História Militar do Brasil. 3. ed. Rio de Janeiro: Civilização Brasileira, 1979. 


\section{DADOS DA PUBLICAÇÃO}

Categoria: artigo submetido ao double-blind review.

Recebido em: 10/06/2018.

Aceito em: 30/06/2019. 
